\title{
DESAIN PORTABLE ANDROID THERMOMETER FEVER (PROMETER): TERMOMETER NON-KONTAK PRAKTIS BERBASIS ANDROID
}

\author{
Bima Agung Setyawan ${ }^{1}$, Tiar Agustianto ${ }^{2}$, Syukri Fathudin Achmad Widodo ${ }^{3}$ \\ 1,2,3Pendidikan Teknik Mesin, Fakultas Teknik, Universitas Negeri Yogyakarta \\ Email: bimaagung.2018@student.uny.ac.id
}

\begin{abstract}
Vocational education plays an essential role in the corona pandemic case because it is a direct benchmark for applying science to a cultured society's environment. One of the applications is the development of tools to prevent the spread of COVID-19. The idea arises from the fact that gun thermometers, which are a vital tool to prevent pandemic spread, were scarce and expensive. The proposed solution was to develop a device called Portable Android Thermometer Fever (PROMETER), a suitable non-contact thermometer based on Android. The method was research and development. Data were analyzed using a qualitative descriptive approach. From the study results, it can be concluded that the PROMETER can be used as an accurate and practical gun-type thermometer.
\end{abstract}

Keywords: covid-19, personal protective equipment, firing thermometer

\begin{abstract}
ABSTRAK
Pendidikan kejuruan mengambil peran penting dalam kasus pandemi corona karena pendidikan kejuruan menjadi tolak ukur pengaplikasian langsung ilmu-ilmu untuk dapat dimanfaatkan dalam lingkungan masyarakat yang berbudaya. Salah satu pengaplikasian ilmu teknologi dalam pendidikan kejuruan yakni dengan pembuatan alat atau sistem sebagai bentuk solusi pencegahan penyebaran covid-19. Dari studi kasus tentang kelangkaan dan mahalnya termometer tembak yang menjadi alat penting dalam penanganan kasus penyebaran covid-19 didapat suatu gagasan desain alat yang diberi nama Portable Android Thermometer Fever (PROMETER): Termometer Non-Kontak Praktis Berbasis Android Sebagai Alat Pemantau Suhu Badan Dalam Penanggulangan Penyebaran Covid-19. Bentuk penelitian ini adalah research and development. Dari data hasil penelitian diperoleh data yang dianalisis secara kualitatif deskriptif. Dari hasil penelitian dapat ditarik kesimpulan bahwa Portable Android Thermometer Fever (Prometer)dapat digunakan sebagai termometer tembak yang akurat dan praktis.
\end{abstract}

Kata kunci: covid-19, alat perlindungan diri, termometer tembak

\section{PENDAHULUAN}

Virus corona atau yang dinamakan virus SARS-CoV-2 merupakan virus yang dapat menyebabkan infeksi pernapasan berat, seperti infeksi paru-paru (pneumonia), Middle East Respiratory Syndrome (MERS), dan Severe Acute Respiratory Syndrome (SARS) (Kannan et al. 2020). Virus ini merupakan pengembangan dari SARS Cov 2 (Xu et al. 2020). Fakta bahwa virus corona merupakan virus yang masih sulit disembuhkan karena pengujian klinis vaksin sedang berlangsung di banyak negara (Pandey et al. 2020). Virus corona ini dapat menginfeksi siapapun, sehingga virus ini sangat cepat dapat menularkan dari manusia ke manusia. Kecepatan penularan Covid-19 ini dapat disebabkan kontak langsung antara pasien suspek dan non-suspek karena tidak menerapkan protokol kesehatan.

Data yang berkembang saat ini menunjukkan lonjakan angka positif Covid-19 di Indonesia namun beberapa negara yang dahulu mengalami lonjakan sekarang ini sudah menurun. Hingga saat ini pencegahan yang dapat dilakukan agar penularan virus ini tidak terjadi yaitu dengan menjaga jarak, hindari keramaian dan tidak bepergian (Azanella 2020). Namun faktanya, beberapa para pekerja, seperti pekerja 
harian,mereka harus tetap bekerja untuk menghidupi keluarganya. Berdasarkan penelitian yang melibatkan hampir 140 pasien di Rumah Sakit Zhongnan, Universitas Wuhan, China, Sekitar 99 persen pasien yang positif terkena virus corona mengalami suhu tinggi atau demam. Gejala tersebut ditandai dengan meningkatnya suhu tubuh lebih dari 38 derajat celcius. Sementara suhu tubuh normal berkisar 36,1 hingga 37,2 derajat (Arnani, 2020). Oleh karena itu, salah satu metode pencegahan yang banyak dilakukan saat ini adalah pemeriksaan suhu tubuh untuk mendeteksi adanya virus corona.

Metode pengecekan suhu saat ini banyak diterapkan di sejumlah fasilitas umum seperti bandara, perkantoran, hingga istana negara dengan memanfaatkan alat termometer baik yang scanner dan tembak. Alat ini dinilai cukup baik untuk mendeteksi suhu tubuh pada saat pandemi ini karena bisa bekerja tanpa menyentuh bagian tubuh seperti termometer biasa (Crossley 2020). Langkanya thermometer digital pada saat pandemi serta meningkatnya harga produk tersebut menyebabkan keberadaan alat ini tidak secara masif ada di tempat perkantoran, keramaian, dan tempat umum. Disamping itu, harga termometer tembak cukup mahal bahkan mencapai jutaan rupiah untuk mendapatkan kualitas yang baik dan valid. Banyak kasus termometer tembak murah tidak akurat sehingga menjadi sangat berbahaya karena memberikan informasi yang salah. Selain itu, alat ini dinilai kurang praktis karena penggunaannya cukup rumit dan mobilitas yang kurang baik.

Berkaitan penjelasan di atas, pendidikan kejuruan mengambil peran penting dalam kasus pandemi ini karena pendidikan kejuruan menjadi tolak ukur pengaplikasian langsung ilmu-ilmu untuk dapat dimanfaatkan dalam lingkungan masyarakat yang berbudaya. Salah satu pengaplikasi ilmu teknologi dalam pendidikan kejuruan yakni dengan pembuatan alat atau sistem sebagai bentuk solusi pencegahan penyebaran covid-19.
Berdasarkan latar belakang masalah di atas, solusi untuk mengatasi permasalahan akibat kelemahan termometer tembak adalah dengan membuat alat pengecek suhu tubuh yang murah, akurat, praktis dan dapat diproduksi dalam jumlah banyak. Oleh karena itu, diperlukan desain alat bernama Portable Android Thermometer Fever (PROMETER). PROMETER yang merupakan sebuah termometer non kontak yang didesain praktis, serta dapat digunakan dengan mudah dan memiliki mobilitas yang baik, serta berbasis android.

PROMETER di desain untuk mampu mengecek suhu dengan akurat dan informasinya dapat ditampilkan pada perangkat android yang terhubung. Selain itu, biaya pembuatan alat ini diharapkan terjangkau, kompetitif dengan harga termometer tembak saat ini, dan materialnya tersedia di pasaran sehingga dapat diproduksi secara massal. Adanya PROMETER ditengah pandemi diharapkan dapat memudahkan masyarakat melakukan tindak pencegahan virus corona melalui pengecekan suhu tubuh secara optimal. Dengan begitu pencegahan penyebaran covid-19 dapat dilakukan sejak dini dan orangorang yang harus bekerja di luar rumah bisa bekerja dengan aman.

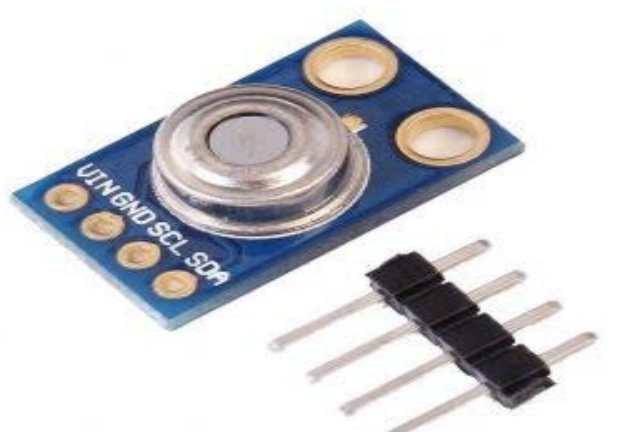

Gambar 1. Modul GY-906 MLX90614 (Sumber:nn-digital.com)

PROMETER menggunakan mikrokontroler berupa NodeMCU ESP 8266 dan sensor suhu GY-906 MLX90614. NodeMCU ESP 8266 merupakan sebuah platform IoT yang bersifat open source, terdiri dari perangkat keras berupa System On Chip ESP8266 buatan Espressif System dan firmware yang 
menggunakan bahasa pemrograman Scripting Lua. Istilah NodeMCU secara default sebenarnya mengacu pada firmware yang digunakan pada perangkat keras development kit. ESP8266 merupakan modul WiFi yang berfungsi sebagai perangkat tambahan mikrokontroler seperti arduino agar dapat terhubung langsung dengan WiFi dan membuat koneksi TCP/IP (Anonim, 2018).Mikrokontroler ini menggunakan tegangan 3,3 volt. Karena mikrokontroler ini telah dilengkapi GPIO, memori dan prosesor sendiri, maka mikrokontroler ini dapat berdiri sendiri tanpa menggunakan mikrokontroler lain.

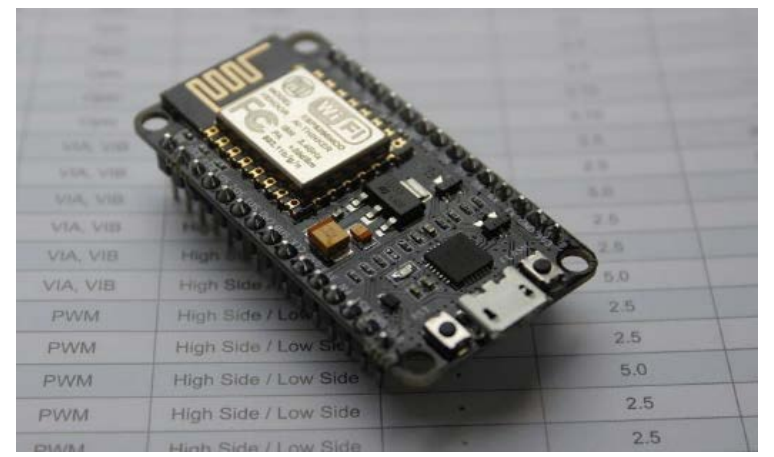

Gambar 2. NodeMCU ESP8266

(Sumber: myarduino.net)

Untuk sensor suhu yang dipakai yakni sensor GY-906 MLX90614. Sensor ini merupakan sensor inframerah untuk pengukuran suhu nonkontak. Pengondisi sinyal yang terintegrasi ke dalam MLX90614 adalah low noise amplifier, 17-bit ADC dan unit DSP yang kuat sehingga mencapai akurasi dan resolusi tinggi dari termometer.Secara default dari pabrik, sensor dikalibrasi dengan output SMBus digital yang memberikan akses penuh ke suhu yang diukur dalam kisaran suhu lengkap dengan resolusi $0,02^{\circ} \mathrm{C}$ (Anonim, 2019).

\section{METODE PENELITIAN}

Penelitian ini merupakan jenis penelitian dan pengembangan atau Research and Development (R\&D). Metode penelitian dan pengembangan (Research and Development) merupakan metode penelitian yang digunakan untuk menghasilkan produk tertentu, dan menguji keefektifan dari produk tersebut (Sugiyono 2013). Metode penelitian ini adalah pengembangan dari model pengembangan 4-D (Four-D models) (Thiagarajan, Semmel, and Semmerl 1974)

Penelitian ini dilaksanakan di laboratorium pneumatik Jurusan Pendidikan Teknik Mesin Fakultas Teknik, Universitas Negeri Yogyakarta.

Tahapan-tahapan yang dilakukan pada penelitian ini yaitu: (1) pendenifisian, (2) perancangan, (3) pengembangan, dan (4) penyebaran.Tahap perencanaan bertujuan untuk menganilis inovasi dari alat ini agar selaras dengan tujuan dan manfaat dari alat Prometer ini untuk memecahkan kasus yang diangkat yaitu pembuatan alat pengecek suhu badan untuk penangulangan Covid-19. Tahap perancangan (design) bukan hanya membahas suatu desain alat tetapi proses apa saja yang harus dilakukan sebelum membuat alat Prometer ini. Adapun aliran analisis proseses dari alat disampaikan dalam Gambar 3.

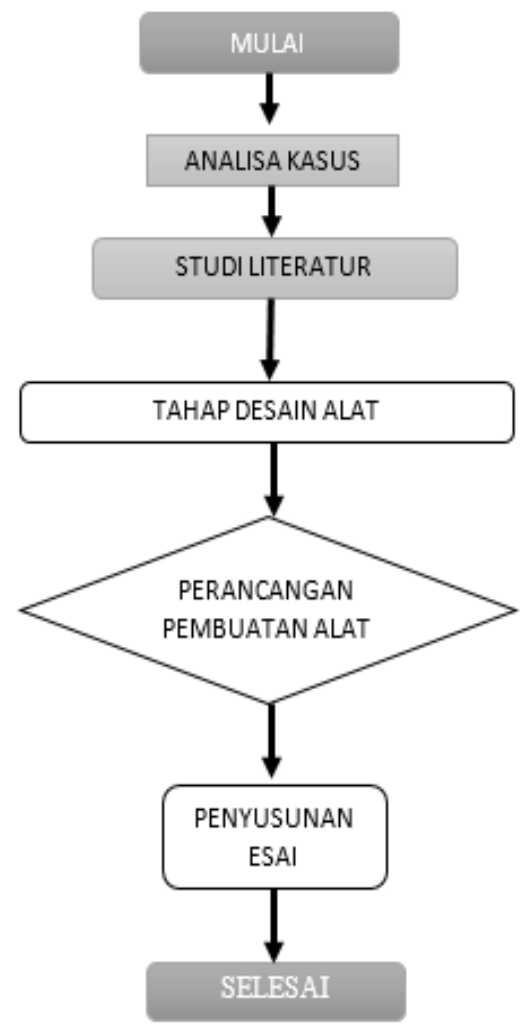

Gambar 3. Diagram Alir Perancangan 
Pembuat desaian dari produk ini mempertimbangkan dari fungsi, kenyamanan, dan estetika. Untuk tahap selajutnya penentuan material yang sesuai dengan produk ini yaitu bahan yang mudah didapat dengan harga murah Produk ini didesain menggunakan software CAD Inentor 2019 student version.

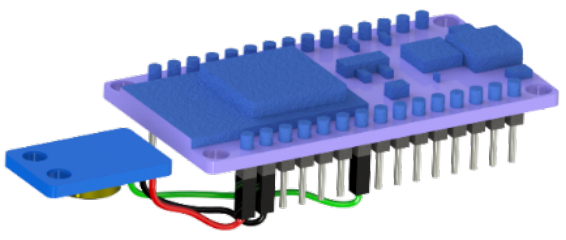

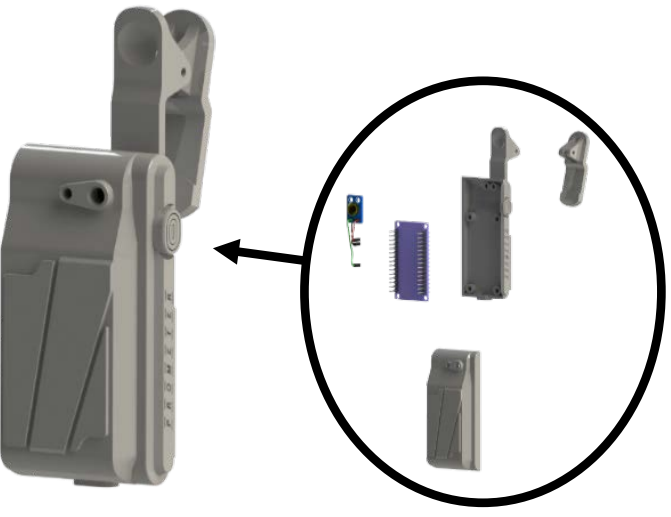

Gambar 5. Rancangan desain PROMETER

Gambar 4. Rangkaian Mikrokontroler dan Sensor IR
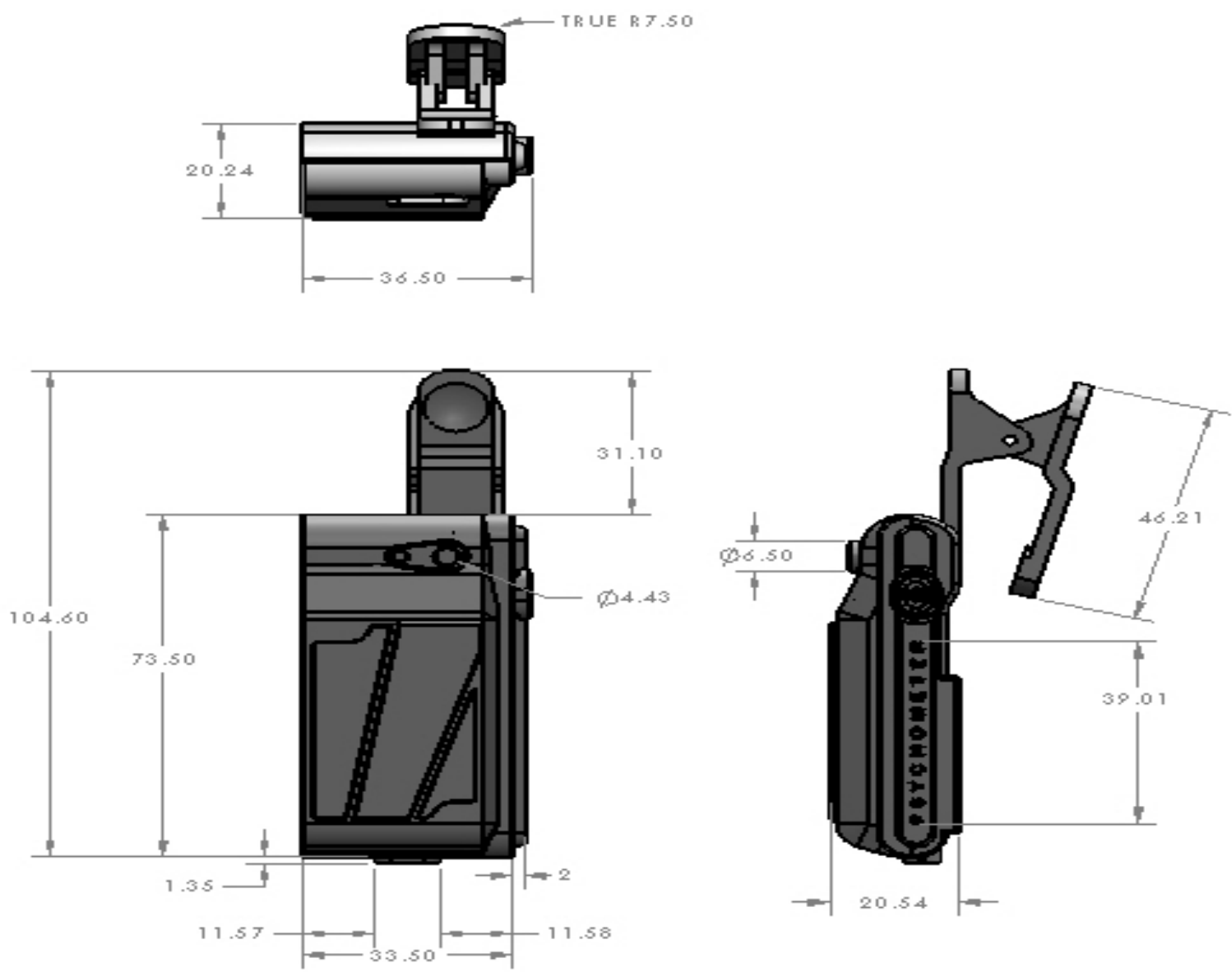

Gambar 6. Dimensi PROMETER

Tahap selanjutnya adalah pengembangan (develop). Pada tahap ini desain alat dikembangkan kembali untuk dapat divisualkan cara penggunaanya. Dari tahap ini didapat gambar yang menjelaskan cara pengaplikasian alat ini yakni dengan menggunakan smartphone android sebagai display suhu yang dibaca oleh sensor. 

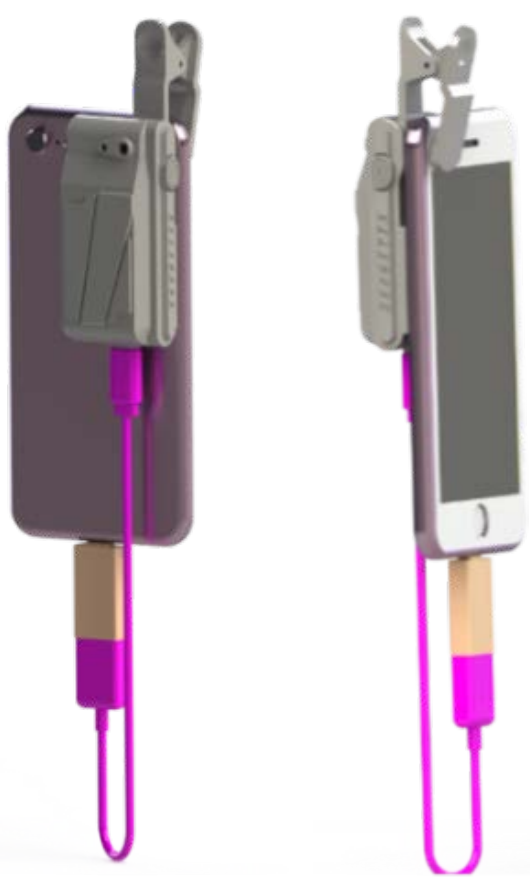

Gambar 7. Gambaran Pengaplikasian PROMETER

Tahap selanjutnya, yaitu publikasi (disseminate). Tahap ini merupakan pembuatan karya ilmiah dari penelitian yang dilakukan terhadap alat ini untuk kemudian karya ilmiah tersebut dipublikasiakan Tujuan dari tahap ini adalah untuk menyebarluaskan innovasi ini agar berguna bagi masyarakat luas khusunya pada pandemi Covid-19 saat ini.

\section{HASIL DAN PEMBAHASAN}

Dari analisa kasus dan studi literatur didapatkan sebuah desain alat berupa termometer non kontak praktis berbasis android yang diberi nama Portable Android Thermometer Fever (Prometer). Desain yang telah dibuat kemudian dilakukan pencetakan dan uji coba. Tahap pencetakan alat ini menggunakan 3D printing yang dimulai dari mengkonversikan file .STL hasil desain menggunakan software Inventor 2019 student version menjadi format file gcode dengan menggunkan software Cura. Format file g.code tersebut yang kemudian dimasukkan ke printer 3D untuk dilakukan proses pencetakan. Gambar 8 menunjukkan hasil proses konversi dari format file .STL menjadi format file .gcode.

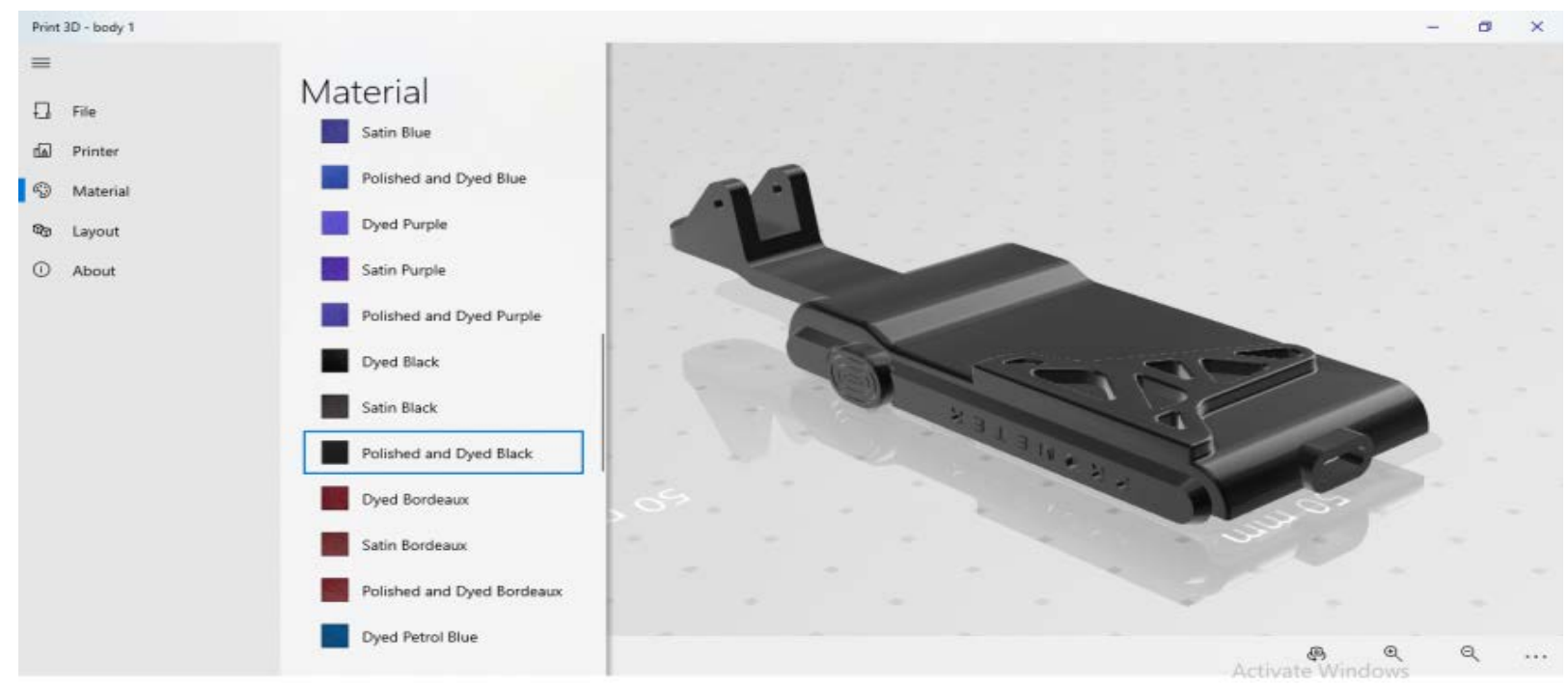

Gambar 8. Hasil Konversi File .STL Menjadi File .gcode

Dari hasil konversi file yang telah dilakukan, selanjutnya adalah proses cetak menggunakan 3D printing. Material yang digunakan adalah plastik jenis PLA (Polylactic Acid). Material ini dipilih karena PLA merupakan jenis plastik biodegradable yang ramah lingkungan. Selain itu material ini juga familiar digunakan dalam dunia 3D printing karena kemudahannya untuk diproses. Gambar 9 merupakan tahap pencetakan menggunakan 3D printing. 


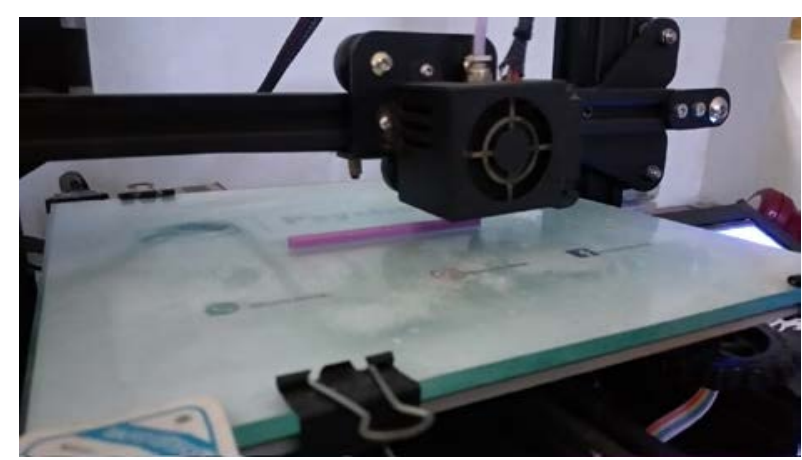

Gambar 9. Proses Pencetakan Menggunakan 3D Printing

Hasil proses pencetakan menggunakan 3D printing yang telah dilakukan, selanjutnya masuk ke proses assembly, yakni merangkai komponen yang diperlukan. Komponen tersebut yakni mikrokontroller dan sensor IR. Setelah proses assembly, selanjutnya adalah tahap uji coba alat. Sistem kerja alat ini menggunakan aplikasi Blynk yang ada pada smartphone android. Berikut adalah cara penggunaan alat ini.

Cara Penggunaan PROMETER memiliki beberapa langkah. Langkah pertama adalah mengunduh terlebih dahulu aplikasi Blynk pada perangkat android.

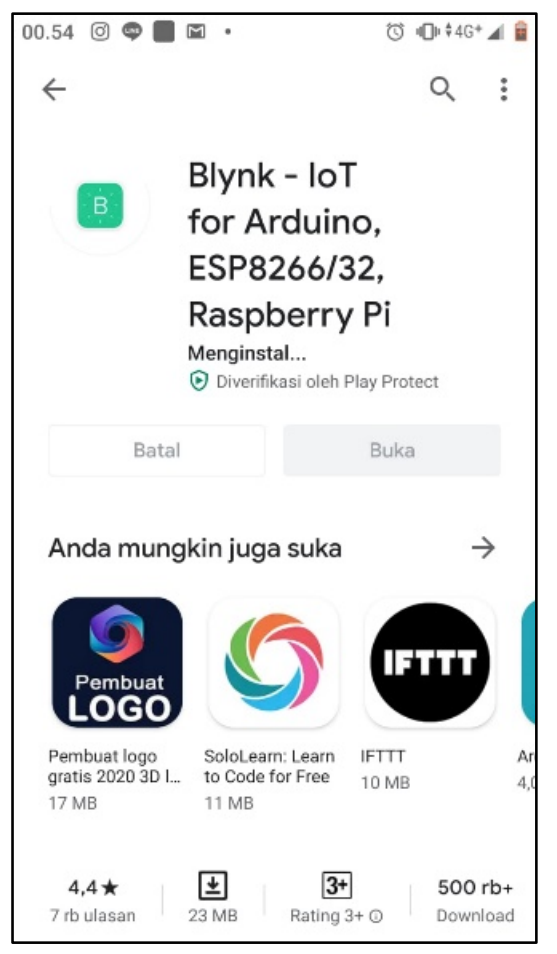

Gambar 10. Proses Download Aplikasi Blynk
Langkah kedua, menghubungkan perangkat android dengan PROMETER menggunakan kabel USB. Buka aplikasi Blynk yang telah didownload, lalu log in dengan google/facebook. Pilih Create New Project masukkan nama PROMETER. Pada pilihan choose device pilih nama mikrokontroler yang digunakan yakni ESP8266, kemudian tekan Create.

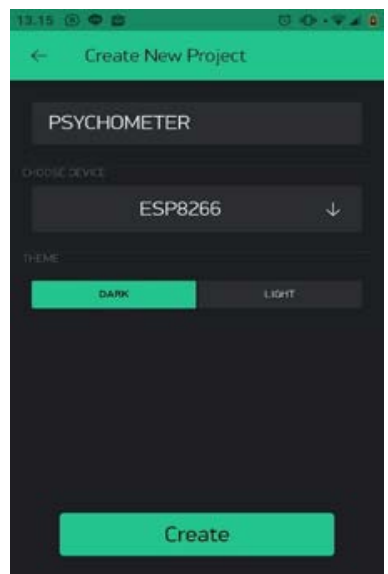

Gambar 11. Proses Penambahan New Project Pada Aplikasi Blynk

Langkah selanjutnya yakni penambahan widget dengan klik tombol widget box, kemudian pilih widget yang digunakan yakni button dan value display.

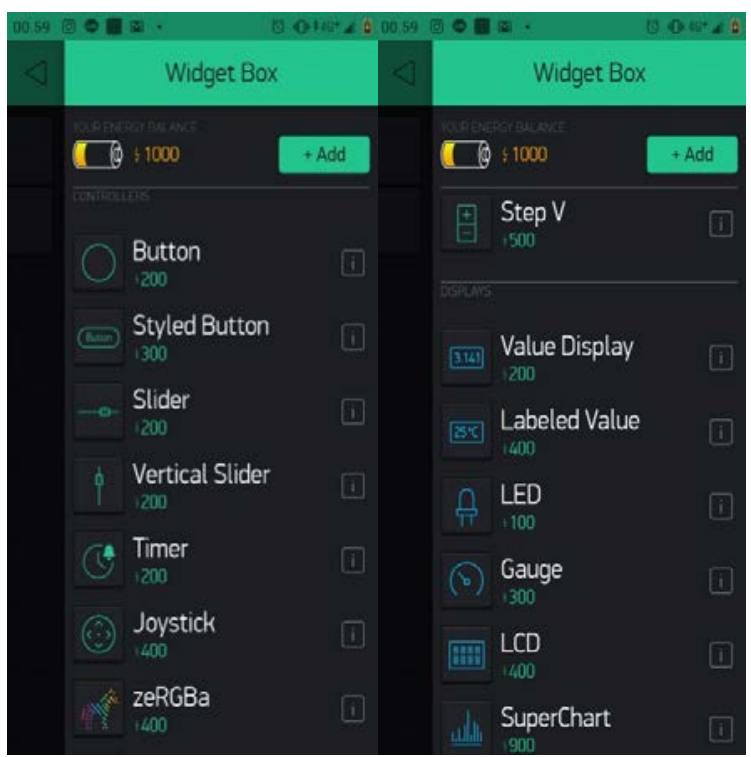

Gambar 12. Proses Penambahan Widget Pada Aplikasi Blynk 
Aplikasi Blynk sudah bisa digunakan sebagai display suhu dari PSYCHOMETER. Yakni dengan klik tombol On dan Off untuk mendeteksi suhu baru.
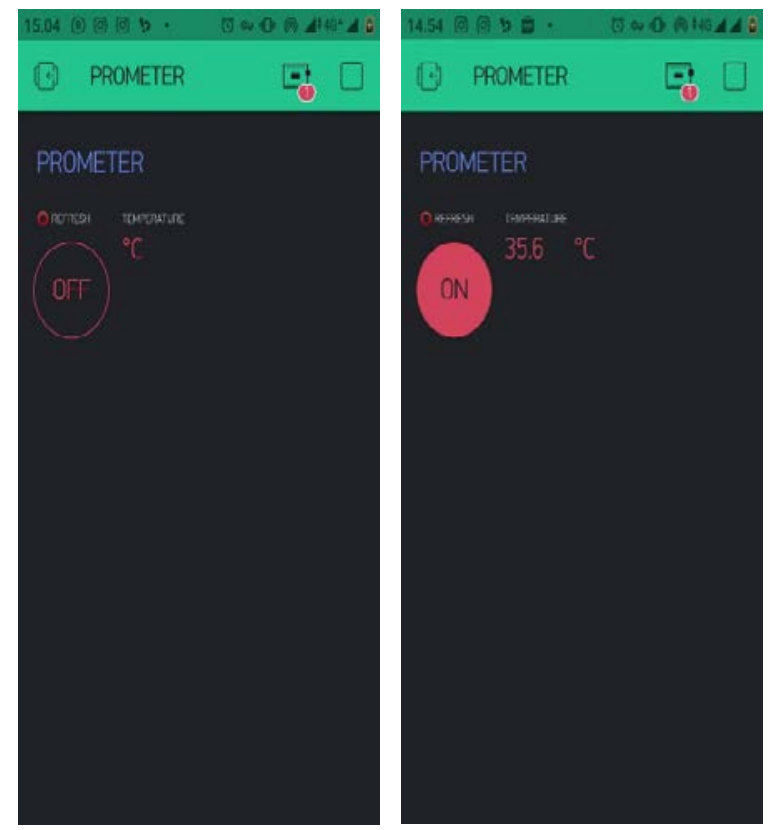

Gambar 13. Cara Baca Suhu Pada Aplikasi Blynk yang Terhubung dengan PSYCHOMETER

\section{SIMPULAN}

Portable Android Thermometer Fever (PROMETER) menjadi salah satu trobosan untuk secara cepat memutus rantai penyebaran virus corona dengan mengetahui lebih dini kondisi tubuh dengan memantau suhunya. Prinsip kerja alat ini sama seperti thermometer gun pada umumnya, namun display yang digunaan menggunakan perangkat smartphone android. Sistem kontrol pada alat ini menggunakan mikrokontroler NodeMCU ESP8266 yang juga sebagai modul WiFi dan sensor suhu IR (Infrared) GY-906 MLX90614. Alat ini dibuat dengan nilai kepraktisan untuk memudahan mobilitas dan pemakaian.

\section{DAFTAR RUJUKAN}

Arnani, Mela. 2020. Waspadai, Berikut Ciri-ciri Terinfeksi Virus Corona Hari Pertama
Hingga Ketujuhbelas. URL:

https://www.kompas.com/tren/read/

2020/03/25/190000165/waspadai-berikut-

ciri-ciri-terinfeksi-virus-corona-hari-

pertama-hingga. Diakses pada 11 Mei 2020.

Azanella, Luthfia Ayu. 2020. "Panduan Protokol Kesehatan Pencegahan Covid-19 Untuk Sambut New Normal.” KOMPAS.com.

Crossley, Becky. 2020. “Accuracy of Various Thermometer Types Is Important to Consider during the COVID-19 Pandemic.” Biomedical Instrumentation and Technology.

Kannan, S., P. Shaik Syed Ali, A. Sheeza, and K. Hemalatha. 2020. "COVID-19 (Novel Coronavirus 2019) - Recent Trends.” European Review for Medical and Pharmacological Sciences.

Pandey, Satish Chandra et al. 2020. "Vaccination Strategies to Combat Novel Corona Virus SARS-CoV-2." Life Sciences.

Sugiyono. 2013. Metode Penelitian Kuantitatif, Kualitatif Dan R\&D. Bandung, Indonesia: Bandung: Alfabeta.

Thiagarajan, Sivasailam, Dorothy S. Semmel, and Melvyn I. Semmerl. 1974. Instructional Development for Training Teachers of Exceptional Children: A Sourcebook. Bloomington: Indiana University.

Xu, Jiabao et al. 2020. "Systematic Comparison of Two Animal-to-Human Transmitted Human Coronaviruses: SARS-CoV-2 and SARS-CoV.” Viruses. 